\title{
The Influence of e-Content on Academic Performance and Retention Ability in Learning Mathematics among High School Students - Solomon Four Equivalent Group of Experimental Design
}

Prabakaran B, Ph.D, Research Scholar, Department of Education, Alagappa University, Tamil Nadu, India

Saravanakumar AR, Assistant Professor, Department of Education, Alagappa University, Tamil Nadu, India

Article History: Received: 10 November 2020; Revised 12 January 2021 Accepted: 27 January 2021; Published online: 5 April 2021

\begin{abstract}
The study aims to find out the more influence on the academic performance and the retention ability after receiving the subject concept through pedagogical methods such as conventional and modern methods of teaching. The investigator used the pre, the post and the retention tests for Solomon FourGroup Design of the experiment in this research. The convenient sampling technique which was adopted by selecting a sample of 20 students of the Ninth standard for each group was assigned to the conventional and modern method of teaching. The e-content development module and a standardized researcher's achievement test were developed by the researcher under the guidance of the research supervisor based on the Mathematics subject portion as set theory including skills of drawing the Venn diagram. Levene, ANOVA, Bonferroni, $\omega 2$, r2, Effect Size (d) and Gain Ratio tests are used for statistical analysis and interpretation of achievement and retention scores (data) and the results are discussed in this paper along with the findings and recommendations.
\end{abstract}

Key Words: e-Content Module of Learning, Chalk and Talk Method of Teaching, Solomon Four Group Design, Learning Mathematics, Academic Performance, Retention Ability, Levene Homogeneity of variances, Bonferroni.

\section{INTRODUCTION}

Set language is a language which is used in a vast area in mathematics such as Algebra, Topology, Functional Analysis, discrete mathematics, mathematical analysis and so on. Application of it may be solved some kinds of problems in the practical life. Examples: IPL schedule of cricket matches may be prepared by using the set language. The selection of batsmen, bowlers, fielders and players of all-rounder may be followed by the application of a set language easily. Teaching the reading comprehension by using the Venn diagram technique increased the students' achievement in descriptive text (Malasari, 2017 and Emi Agusriani Samosir, 2013).

\section{SIGNIFICANCE OF THE STUDY}

Mathematics is a foundation of all subjects, especially sciences. Unless everyone discontinues due to stagnation and wastage, everyone must learn mathematics upto the tenth standard. 
Learners learn the subject matter through interest, motivation and self-direction. Any teaching method is to be created to the student's interest, motivating him or her to learn continuously, having the concept depth and clarifying the doubts, providing rich experiences of the learners own thoughts. The e-content is a teaching-learning module in modern trends. E-content attracts students towards mathematics learning for the purpose of enrichment of subject content. It is an application of everyone's critical situation of the real life. Mathematics is not a very tough subject, but a suitable teaching method fulfills the need for abolishing the wrong notion of this world perception of Mathematics. The e-content deliveries facilitate students' learning with avoiding the rote memory without understanding the meaning.

\section{OBJECTIVES}

1. To calculate the homogeneity and value of the equivalent groups.

2. To calculate the average academic performance and retention in learning mathematics between e-content module of learning and chalk and talk method of teaching among ninth standard students.

3. To calculate the effect size values and gain ratios between the e-Content Module of Learning and the Chalk and Talk Method of Teaching among ninth standard students.

\section{REVIEWS OF THE RELATED LITERATURES}

The following reviews are referred to this research article writing: Abiola Lateef Olori and Adekunle Olusegun Igbosanu (2016), Adediran Adekunle Amosa, Fayemi John Adelanib and Adebajo, Y. Adebola (2015), Alice Latimier et al (2019), Allan Ayittey, Amutha, S. (2016 \& 2011), Emmanuel Arthur-Nyarko and Francis Onuman (2019), Andi field (2016), Anna Laszlo (2017), Ball, AK. (2016), Bruce Jerome Carter (2017), Cyril, M. U. (2016), Devendiran, G., Vakkil, M. (2017), Dolník,V (2018), Govindaraj, S. (2017), Hilal Almara'beh, Ehab F. Amer, Amjad Sulieman (2015), Iqbal Shah, Muhammad Khan (2015), Ilknur Gulsen Turgut and Sedat Turgut (2018), Ismail, D. (2017), Jebaraj and Mohanasundaram (2015), Jennifer L. Seymour (2016), Joseph, Manju (2015), Joyline Mugero Muchiri (2018), Kumar, Raman and Kaur, Jagpreet (2018), Koopman, L. (2017), Kutiriko et al (2019), Manikandan (2017), Mamun Ali Naji Qasem (2015), Meliha zeinilagic-Hajric, Nizama Beganovic and Ines Nuic (2016), Muhammad Shamim (2018), Munni Kumari (2017), Lei, Y. (2016), Murali Vipul and Jaise Jaya (2016), Muruganantham (2015), Muthukumari, J and Ramakrishnan, M. (2017), Muthulakshmi, P. (2016), Nair Sobhana Nandakumar (2015), Najeh Rajeh Alsalhi, Mohd. Elmagzoub Eltahir, and Sami Sulieman Al-Qatawneh (2019), Nwanze, A.C. (2018), Rajkumar, R. and Hema, G. (2018), Sajna Jaleel (2015), Salah Zogheib et al (2015), Sautiere, P.E., Blervacq, A.S. and Vizioli, J. (2019), Sakiyo John, Aishatu Ahmad Musa and Kawu Waziri (2018), Sathya, T. (2016), Sengamalaselvi, J. (2016), SenthamaraiKannan. B et al (2015), Sorzano, C.O.S. and Parkinson, M. (2019), Sudha Kumari, N. (2017), Suresh Prabu, P. (2016), Swati Shukla and Daljeet Kaur (2019), Syamsuddin and Andi Azis Jimi (2019), Thair Hamtini (2017), Tekin, Ahmet and Polat, Ebru (2016), Umar, B. K., Ossom, M. O and Egbita, A. U (2020), Warner, SK. (2015), Zare, M. (2016).

\section{RESEARCH DESIGN}

The researcher adopted the pre, post and retention tests of Solomon Four-Group Design for equivalent groups in this research. One control group and one experimental group with the pre- 
achievement tests, the post-achievement tests and the retention tests of achievement are administered before and after taught through the Chalk and Talk Method of Teaching and the e-Content Development Module of Learning respectively. And also, one control group and one experimental group with the post-achievement tests and the retention tests of achievement are administered after being taught through the Chalk and Talk Method of Teaching and the eContent Development Module of Learning, respectively.

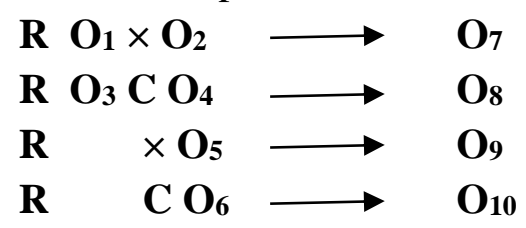

In this design

1. Subjects are purposively assigned to two groups

2. Two Experimental Groups Received the Treatment such as interactive e-content module of learning $(x)$.

3. Two Control Group received the conventional method of teaching such as chalk and talk method of teaching $(\mathrm{C})$

4. Two groups is managed the pre- achievement tests $\left(\mathrm{O}_{1}\right.$ and $\left.\mathbf{O}_{3}\right)$

5. Four groups receive the post-achievement tests $\left(\mathrm{O}_{2}, \mathrm{O}_{4}, \mathrm{O}_{5}\right.$ and $\left.\mathrm{O}_{6}\right)$

6. Four groups receive the retention tests $\left(\mathrm{O}_{7}, \mathrm{O}_{\mathbf{8}}, \mathrm{O}_{9}\right.$ and $\left.\mathrm{O}_{10}\right)$ after 30 days from conducting the post-tests.

7. All four groups are homogeneous and equivalent groups.

Ficture-1: Solomon Four Design with the Pre, Post and the Retention Tests

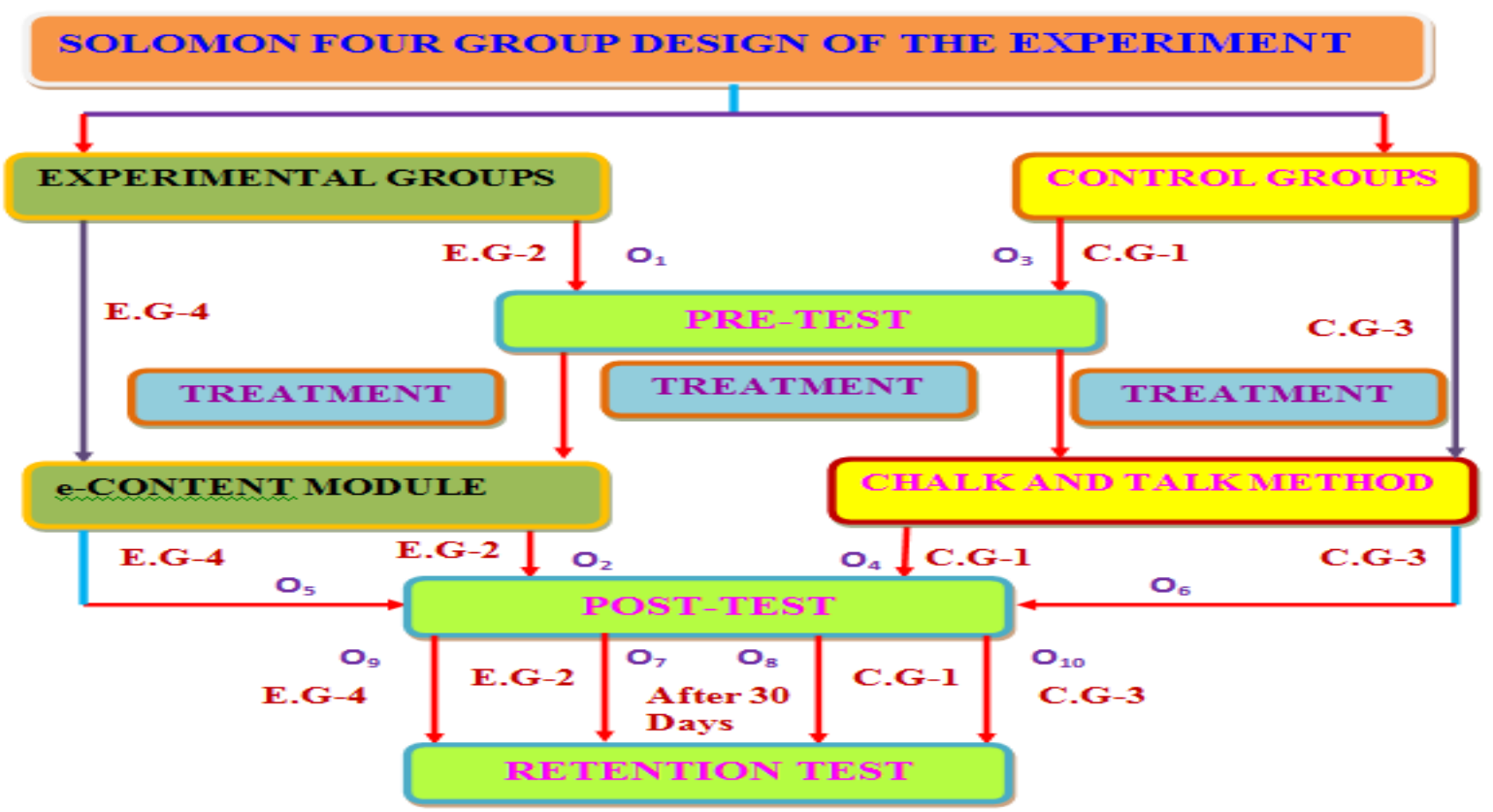

Where C.G-1 refers Conventional Group-1, E.G-2 refers Experimental Group-2,

C.G-1 refers Conventional Group-3, E.G-2 refers Experimental Group-4, N=20 in each group. 


\section{POPULATION OF THE STUDY}

The population for the study was considered the Ninth standard students in the State Board of Tamil Nadu.

\section{ACCESSIBLE POPULATION}

The accessible population for the study was considered the Tamil medium students of Ninth standard in the State Board of Pudukkottai District, Tamil Nadu.

\section{SAMPLE}

Four groups contained 80 Tamil medium students of the Ninth standard for conducting the experiments. Each group contained 20 students. The Control Groups received the conventional teaching method such as the Chalk and Talk method of teaching which is provided through their class teachers and the Experimental Groups received the modern teaching method such as the interactive e-content development module of learning which is provided through the MP4 video lesson by using the LCD projector. Two schools are chosen for conducting the experiments. Four groups are assigned the equivalent and homogeneous groups which are formed by using their half-yearly examination marks of the students.

\section{RESEARCH TEACHING-LEARNING MODULE}

The Interactive E-Content Module of Teaching is presented for the experimental groups and the Chalks and Talk Methods Teaching is taught by the class teacher.

\section{RESEARCH TOOL}

The present study has used the following tool: Achievement Test in the Mathematics unit 'Set Language' is prepared and standardized by the investigator.

\section{INTERPRETATION OF DATA}

\section{Hypothesis-1}

Selected groups have homogeneous variances and equivalent groups to each other before participating in the experiments.

Table-1: Levene Test of Homogeneous Variances and ANOVA-Test of Equivalent Groups

\begin{tabular}{|c|c|c|c|c|c|c|c|}
\hline Marks & $\begin{array}{c}\text { Levene } \\
\text { statistics }\end{array}$ & Sig. & $\begin{array}{l}\text { Sum of } \\
\text { squares }\end{array}$ & $\mathrm{df}$ & $\begin{array}{l}\text { Means } \\
\text { square }\end{array}$ & $\mathrm{F}$ & Sig. \\
\hline Between groups & \multirow[t]{3}{*}{1.396} & \multirow[t]{3}{*}{.251} & 274.2 & 3 & 91.4 & \multirow[t]{3}{*}{0.564} & \multirow[t]{3}{*}{0.64} \\
\hline Within groups & & & 12306.6 & 76 & 161.929 & & \\
\hline Total & & & 12580.8 & 79 & & & \\
\hline
\end{tabular}

The table shows that value of Levene (1.396) and F-value (0.564) is less than table value of $F(4.0503)$ and also the significant value of Levene (.251) and the significant value of $\mathrm{F}(0.64)$ is greater than the selected significant level value $\alpha(0.01)$. From these interpretations, the null hypothesis is not rejected. Therefore, selected groups have homogeneity of variances and equivalent groups to each other before participating in the experiments is proved. 


\section{Hypothesis-2}

There is no significant difference among the Pre-test, the Post-test and the Retention test of the Academic Attainment in the Mathematics unit Set Language for the Conventional Group-1, the Experimental Group-2, the Conventional Group-3, and the Experimental Group-4 among ninth standard students.

Table-2: ANOVA Test among above Mentioned Four Groups

\begin{tabular}{|l|c|c|l|l|l|l|}
\hline \multicolumn{1}{|c|}{$\begin{array}{c}\text { Source of } \\
\text { Variance }\end{array}$} & $\begin{array}{l}\text { Sum of } \\
\text { Squares }\end{array}$ & df & $\begin{array}{l}\text { Mean } \\
\text { Square }\end{array}$ & $\begin{array}{l}\text { Obtained F } \\
\text {-value }\end{array}$ & $\begin{array}{l}\text { Critical } \\
\text { F-value }\end{array}$ & $\begin{array}{l}\text { Significance } \\
\text { At 0.01 level }\end{array}$ \\
\hline Between groups & 29392.820 & 9 & 3265.869 & $195.211^{* *}$ & 2.5019 & Significance \\
\cline { 1 - 4 } Within groups & 3178.694 & 190 & 16.73 & & & \\
\hline Total & 32571.514 & 199 & & & \\
\hline
\end{tabular}

The table shows that the obtained F-value 195.211 is greater than the critical F-value 2.5019. It means there is a significant difference among the Pre-test, Post-test and Retention test of Achievement in Mathematics unit Set Language for the Conventional Group-1, the Conventional Group-3, the Experimental Group-2 and the Experimental Group-4 among ninth standard students. Therefore, a post hoc test, namely the Bonferroni test, can be applied to find the effectiveness of the conventional method of teaching such as the chalk and talk method and the interactive e-Content Development Module of Learning.

Table-3: Bonferroni Tests for Solomon Four Groups

\begin{tabular}{|c|c|c|c|c|c|}
\hline Between & B-value & Between & B-value & Between & B-value \\
\hline 1 and 2 & $7.0741 * *$ & 2 and 9 & $14.9600 * *$ & 5 and 6 & $4.5228 * *$ \\
\hline 1 and 3 & $3.7883 * *$ & 2 and 10 & $19.9081 * *$ & 5 and 7 & $6.3397 * *$ \\
\hline 1 and 4 & 0.4252 & 3 and 4 & $4.2136 * *$ & 5 and 8 & $9.3162 * *$ \\
\hline 1 and 5 & $18.2072 * *$ & 3 and 5 & $14.4189 * *$ & 5 and 9 & $3.8270 * *$ \\
\hline 1 and 6 & $22.7300 * *$ & 3 and 6 & $18.9417 * *$ & 5 and 10 & $8.7750 * *$ \\
\hline 1 and 7 & $11.8675 * *$ & 3 and 7 & $8.0792 * *$ & 6 and 7 & $10.8625 * *$ \\
\hline 1 and 8 & $8.8910 * *$ & 3 and 8 & $5.1027 * *$ & 6 and 8 & $13.8390 * *$ \\
\hline 1 and 9 & $22.0342 * *$ & 3 and 9 & $18.2458 * *$ & 6 and 9 & 0.6958 \\
\hline 1 and 10 & $26.9822 * *$ & 3 and 10 & $23.1939 * *$ & 6 and 10 & $4.2522 * *$ \\
\hline 2 and 3 & 3.2858 & 4 and 5 & $18.6324 * *$ & 7 and 8 & 2.9765 \\
\hline 2 and 4 & $7.4994 * *$ & 4 and 6 & $23.1552 * *$ & 7 and 9 & $10.1666^{* *}$ \\
\hline 2 and 5 & $11.1331 * *$ & 4 and 7 & $12.2928 * *$ & 7 and 10 & $15.1147 * *$ \\
\hline 2 and 6 & $15.6559 * *$ & 4 and 8 & $9.3162 * *$ & 8 and 9 & $13.1432 * *$ \\
\hline 2 and 7 & $4.7934 * *$ & 4 and 9 & $22.4594 * *$ & 8 and 10 & $18.0912 * *$ \\
\hline 2 and 8 & 1.8169 & 4 and 10 & $27.4074 * *$ & 9 and 10 & $4.9480 * *$ \\
\hline
\end{tabular}

Where 1-refers the pre-test of the control group-1, 2- refers the post-test of the control group-1, 3-refers the retention test of the control group-1, 4-refers the pre-test of the experimental group-2, 5-refers the post-test of the experimental group-2, 6-refers the retention test of the experimental group-2, 7-refers the post-test of the control group-3, 8-refers the 
retention test of the control group-3, 9-refers the post-test of the experimental group-4, 10refers the retention test of the experimental group- 4 .

The table shows that all values are compared with the critical value of Bonferroni (3.7673) at 0.01 level. All values are significant except 1 and 4,2 and 3,2 and 8,6 and 9 and 7 and 8 at 0.01 level.

From 1 and 4, the control group-1 and the experimental group-2 have more or less the same level of academic attainment.

From 2 and 3, no change in the academic attainment for the post test and the retention test of the control group- 1 .

From 2 and 3, no change in the academic attainment for the post test and the retention test of the control group- 1 .

From 2 and 8, no change in the academic attainment for the post test of the control group-1 and the retention test of the control group-3.

From 6 and 9, no change in the academic attainment for the retention test of the experimental group-2 and the post-test of the experimental group-4.

From 7 and 8, no change in the academic attainment for the post-test and the retention test of the control group-3.

Others interpret, the e-content module of learning as influencing the academic attainment and the retention ability in a positive way.

The chalk and talk method of teaching is influencing on academic attainment but not retention ability in a positive way.

\section{Hypothesis-3}

There are no significant differences in the effect sizes and gain ratios between the control groups and the experimental groups.

Table-4: Effect Sizes and Gain Ratios of the Conventional and the Experimental Groups

\begin{tabular}{|l|l|l|l|l|l|}
\hline \multicolumn{1}{|c|}{ Treatment of Teaching } & \multicolumn{1}{|c|}{ Between } & $\begin{array}{l}\text { Effect } \\
\text { size }(\mathrm{d})\end{array}$ & $\%$ of $\omega^{2}$ & $\%$ of $\mathrm{r}^{2}$ & \multicolumn{1}{|c|}{$\begin{array}{l}\text { Gain } \\
\text { Ratio }\end{array}$} \\
\hline Chalk and Talk method & $\begin{array}{l}\text { Pre-test-1 and } \\
\text { Retentiontest-1 }\end{array}$ & 1.0302 & 33.58 & 11.22 & 0.1261 \\
\hline & $\begin{array}{l}\text { Posttest-1 } \\
\text { Retention-1 }\end{array}$ & 1.4071 & 49.11 & 58.37 & -0.1431 \\
\hline & $\begin{array}{l}\text { Posttest-3 } \\
\text { Retention-3 }\end{array}$ & 0.8694 & 26.09 & 33.29 & -0.1638 \\
\hline e-Content development module & $\begin{array}{l}\text { Pre-test-2 and } \\
\text { Retentiontest-2 }\end{array}$ & 10.2269 & 98.12 & 38.44 & 0.6117 \\
\hline & $\begin{array}{l}\text { Posttest-2 } \\
\text { Retention-2 }\end{array}$ & 2.1663 & 69.89 & 42.90 & 0.3824 \\
\hline & $\begin{array}{l}\text { Posttest-4 } \\
\text { Retention-4 }\end{array}$ & 1.7341 & 59.65 & 33.18 & 0.2340 \\
\hline
\end{tabular}

The table shows that all the values of Effect Sizes and Gain Ratios in the Experimental Groups are greater than the Conventional Groups. Therefore, the Interactive e-Content Development Module of Learning is more effective than the Chalk and Talk Method of 
Teaching. It is an authentication of the conformation of the effectiveness of the Interactive eContent Development Module of Learning.

\section{FINDINGS}

1. The e-Content Module of Learning is raising the academic attainment and retention ability in learning Mathematics among ninth standard students.

2. The Chalk and Talk Method of Teaching is raising the academic attainment but not retention ability in learning Mathematics among ninth standard students.

3. The e-Content Module of Learning is more effective than the Chalk and Talk Method of Teaching in learning Mathematics among ninth-standard students.

\section{DISCUSSION OF THE FINDINGS}

Findings-1, 2 and 3

The following studies are supported these findings.

Does pre-testing promote better retention than post-testing? By Alice Latimier et al (2019). Both post-testing $(d=0.74)$ and pre-testing effects $(d=0.35)$, with significantly better retention in the former condition.

Effects of Multimedia Instruction on Retention and Achievement of Basic Machining Skills in Mechanical Craft Practice by Cyril, M. U. (2016). The students in the experimental group performed better in mechanical craft practice and in retention test than those in the control group. Hence multimedia instructions have more effect on learning achievement and retention of skills in craft practice.

Effect of Computer Assisted Teaching Strategy on Students Achievement by Gender in Agricultural Education in Tharaka Nithi County, Kenya by Joyline Mugero Muchiri (2018). CAT is an effective strategy in improving achievement in agriculture.

Application of Cognitive Theory of Multimedia Learning in Undergraduate Surgery Course by Muhammad Shamim (2018). The video-based operative sessions are effective mode of teaching general surgery operation in resource limited setting. It is effective in delivering knowledge irrespective of the prior operating exposure or overall satisfaction. applying multimedia design principles during medical lectures improves both long-and short-term retention and transfer tests performances.

Teacher-Assisted Multimedia Instructional Package-An Inevitable Modus to Enhance Retention Capacity of Secondary School Students by Murali Vipul and Jaise Jaya (2016). The Teacher-Assisted Multimedia Instructional Package is highly effective in enhancing Retention Capacity of Process Skills in Physics as compared to the Activity Oriented Method of Instruction.

Effectiveness of E-Content on Achievement in History among IX Standard boys by Muthukumari, J, and Ramakrishnan, M. (2017). Solomon four group design of experimental study is adopted, use of E-Content way of teaching has significant impact on enhancing the achievement in history among the IX standard boys.

Effect of Multimedia Integrated Lessons on Students' Achievement and Retention in Chemistry by Nwanze, A.C. (2018). The multimedia integrated lesson greatly improved students' achievement and retention score in chemistry. Interactive Multimedia Method (IMM) was more effective for English teaching in comparison to Conventional Direct Method and the 
retention is concerned multimedia method of learning is far better than conventional direct method.

Effectiveness of Multimedia Instruction in Better Acquisition of Concepts, Achievement and Retention in Biology among Senior Secondary Level Learners by Swati Shukla and Daljeet Kaur, (2019). Instruction through Multimedia, significantly increased achievement and retention scores in biology among boys and girls in the experimental group.

\section{RECOMMENDATIONS}

The following recommendations are implemented on the basis of the findings.

1. The e-content will be created for all chapters in Ninth Mathematics.

2. The teachers feel free to use the e-content in the classroom.

3. The e-content will be created on the basis of psychological perspectives and steps of teaching models.

4. Teachers provide the e-module to students to teach and revise the studied concept of Mathematics in home studies.

5. Retention abilities enhance through the e-content module, so the module will be made to incorporate various formats such as PPT, video formats, animate pictures, and audio formats etc.

\section{POLICY MAKING}

Students of Government schools are economically, socially and educationally backward. They cannot be unable to buy the mobile phone for learning purpose at the pandemic period and emergency declaration, so the Government will enact the policy making for providing the costless Edu-Phone with installing the learning software features for these students unlike other software features. Marketing Smart phones are not controlled by students while learning. Such advertisements and adult figures are distracting the students' attention and creating maladjustment behaviour against the society.

\section{CONCLUSION}

Nowadays, it needs an alternative method of teaching to the Chalk and Talk Method of Teaching. The Chalk and Talk Method of Teaching can be replaced with the e-Content Module of Learning in these pandemic periods and emergency periods without failing the students' learning. The Chalk and Talk Method is provided in the classroom by the teacher, but e-Content Module of Learning in Mathematics is provided in both classrooms as well as home by the provider.

\section{REFERENCES}

[1]. Aggarwal, J.C. \& Shipra (2017). Psychology of Learning and Development. Delhi: Shipra Publications.

[2]. Alice Latimier et al (2019). Does pre-testing promote better retention than post-testing? npj Science of Learning, 15, 1-7.

[3]. Cyril, M. U. (2016). Effects of Multimedia Instruction on Retention and Achievement of Basic

Machining Skills in Mechanical Craft Practice. International Journal of Education and Information Technology, 2(1), 1-7. 
[4]. Grace Stevens (2020). Teaching in the Post Covid Classroom: Mindsets and Strategies to Cultivate Connection, Manage Behavior and Reduce Overwhelm in Classroom, Distance and Blended Learning. New York: Red Lotus.

[5]. Holly Clark \& Tanya Avrith (2019). The Google Infused Classroom: A Guidebook to Making Thinking Visible and Amplifying Student Voice. Sydney: Elevate Books Edu.

[6]. Jazeel, AM. \& Saravanakumar, AR. (2015). Improving Writing Skills of PGDE Students in English through ICT-Enriched Instructional Approaches, Proceedings of International Research Conference on Humanities and Social Sciences, 123.

[7]. Joe Merrill \& Kristin Merrill (2020). The Interactive Class: Using Technology to Make Learning More Relevant and Engaging in the Elementary Classroom. Elevate Books $\quad$ Edu, Sydney NSW 2000, Australia.

[8]. John W. Creswell (2015). Educational Research - Planning, Conducting, Evaluating Quantitative and Qualitative Research, New York: Pearson publishing.

[9]. Manimekalai, K., \& Sivakumar, I. (2019). Clean India for New India, Chennai MJP.

[10]. Muhammad Shamim (2018). Application of Cognitive Theory of Multimedia Learning in Undergraduate Surgery Course. International Journal of Surgery Research and Practice, $5(2), 1-6$

[11]. Murali Vipul \& Jaise Jaya (2016). Teacher-Assisted multimedia instructional package-An inevitable modus to enhance retention capacity of secondary school students. International Journal of Multidisciplinary Research and Development, 3(8), 227-232

[12]. Muthukumari, J, \& Ramakrishnan, M (2017). Effectiveness of E-Content on Achievement in History among IX Standard Boys. International Journal of Research - Granthaalayah, 5(9:SE), 24-34.

[13]. Nwanze, A.C. (2018). Effect of Multimedia Integrated Lessons on Students' Achievement and Retention in Chemistry. International Journal of Scientific \& Engineering Research, 9(5), 659668.

[14]. Padmini Devi, KR. \& Saravanakumar, AR. (2017). Cognitive dissonance, locus of control, self-efficacy and academic performance of novice teachers, Indian Journal of Research, 6(2), 28-31.

[15]. Prabakaran, B., \& Saravanakumar, AR. (2020). Challenges of E-Content Development Module of Teaching and Learning, Sambodhi, 43(4), 70-72.

[16]. Prabakaran, B. \& Saravanakumar, AR. (2020). E-Content Module is Enhancing the Achievement and Retention Ability in Mathematics among High School Students, Wesleyan Journal of Research, 13(45), 27-38.

[17]. Prabakaran, B. \& Saravanakumar, AR. (2020). Effectiveness of Interactive E-Content Module in Enhancing Students' Achievement in Mathematics. International Journal of Control and Automation, 13(2s), 84-94.

[18]. Prabakaran, B. \& Saravanakumar, AR. (2020). An Interactive E-Content Module for Learning Mathematics -A Single Group Experiment, International Journal of Advanced Science and Technology, 29(5s), 1297-1313.

[19]. Prabakaran, B. \& Saravanakumar, AR. (2021). Effectiveness of E-Content Module in Learning Set Language among Ninth Standard Students-Solomon Four Group Method of the Experimental Study, Turkish Journal of Computer and Mathematics Education, 12(2), 2515-2522.

[20]. Radha, R., Mahalakshmi, K., Sathish Kumar, V. \& Saravanakumar, AR. (2020). E-Learning during Lockdown of Covid-19 Pandemic: A Global Perspective. International Journal of Control and Automation, 13(4), 1088-1099.

[21]. Ramesh Kumar, K., Sivakumar, I., Saravanakumar, N., \& Sathishkumar, R. (2020). Regional Disparities and Indian States: A Macro Level Study, Journal of Critical Reviews, 7(13), 87-92.

[22]. Ravichandran, T. \& Saravanakumar, AR. (2013). Enhancing Biological Sciences Laboratory Experimental Skills through Virtual Laboratory Techniques. Indian Journal of Research. 2(4), 70-72.

[23]. Robert Power (2020). e-Learning Essentials, Sydney: Power Learning Solutions.

[24]. Saravanakumar, AR. \& Subbiah, S. (2011). Teacher Education Programme through Distance Mode a Technological Approach. Indian Journal of Applied Research, 1(3), 56-57. 
[25]. Saravanakumar, AR. \& Padmini Devi, K.R. (2020). Indian Higher Education: Issues and Opportunities. Journal of Critical Reviews, 7(2), 542-545.

[26]. Saravanakumar, AR. (2018). Role of ICT on Enhancing Quality of Education, International Journal of Innovative Science and Research Technology, 3(12), 717-719.

[27]. Saravanakumar, AR. Paavizhi K., \& Balamurugesh, KR. (2020). A Survey on Effectiveness of VideoAssisted Learning in Enhancing Knowledge Competencies for Teachers, Test engineering and management, 82, 5866-5872.

[28]. Saravanakumar, AR. Paavizhi, K. \& Palanisamy, P. (2019). Effectiveness of Video-Assisted Learning Module, International Journal of Control and Automation. 12(06), 268-275.

[29]. Saravanakumar, AR. (2008). Effectiveness of Motivational Strategies on Enhancing Academic Achievement, Journal of Research and Reflections on Education, 16(2).

[30]. Saravanakumar, AR. (2016). Role of ICT in transforming Sri Lankan Higher Education, International Journal of Advanced Research Trends in Engineering and Technology, 3(20).

[31]. Saravanakumar, AR., Paavizhi, K., \& Palanisamy, P. (2019). Effectiveness of Video-Assisted Learning Module. International Journal of Control and Automation, 12(06), 268-275.

[32]. Saravanakumar, AR. (2014). Present Scenario and Future Prospects of Higher Education in India. Proceeding of the Social Sciences Research ICSSR, Kota Kinabalu, Sabah, Malaysia. Organized by http://WorldConferences.net.

[33]. Saravanakumar, AR. \& Paniadima, A. (2017). Cognitive Dissonance, Locus of Control, Self efficiency and Academic Performance of Novice Teachers, Journal of Research and Reflection of Education, 6.

[34]. Saravanakumar, AR. \& Padmini Devi, KR. (2020). Indian Higher Education: Issues and Opportunities, Journal of Critical Reviews, 7(2), 542-545.

[35]. Subbiah, S., Saravanakumar, AR. \& Perumal, R. (2012). Multidimensional practices in teacher education (TE) through distance education (DE), Indian Streams Research Journal, 1(2), 1-4.

[36]. Shandru, Mariyadas \& Saravanakumar, AR. (2021). Conflicts between Staff: Causes and Effects of School's Activities, Indian Journal of Natural Sciences, 11(64), 1-7.

[37]. Sivakumar, I. \& Anitha, M. (2014). "Girl Children and Education an Empirical Study in Puducherry", Modern Education: Women and Weaker Section (eds), Chennai: MJP, 133-142.

[38]. Sivakumar, I. \& Usha, VT. (2013). "Towards Empowerment Educational Status of Women in Fishing Community", Inclusive Economic growth in India: Issues, Challenges and Implications (eds), Chennai: Valar Pirai, 175-184.

[39]. Suman Lata \& Khatri, H.L. (2016). Educational Technology: Pedagogy and ICT Integration Across the Curriculum, Delhi: Shipra Publication.

[40]. Susannah bowen (2015). e-Learning, e-Content, e-Technology. New York: McGraw-Hill.

[41]. Swati Shukla \& Daljeet Kaur (2019). Effectiveness of Multimedia Instruction in Better Acquisition of Concepts, Achievement and Retention in Biology among Senior Secondary Level Learners. ENSEMBLE, 1(2), 8-18.

[42]. Wan Ng (2015). New Digital Technology in Education: Conceptualizing Professional Learning for Educators. New York: Springer. 